\title{
Rheological properties and biscuit production from flour blends prepared from cereal based by-products
}

\author{
Tahıl bazlı yan ürünler ile hazırlanan un karışımlarının reolojik özellikleri ve bisküvi \\ üretimi
}

\author{
Sibel YAĞCl ${ }^{1}$ iD \\ ${ }^{1}$ Karamanoğlu Mehmetbey University, Food Engineering Department, Karaman, Turkey
}

\begin{abstract}
To cite this article:
Yağcı, S. (2019). Rheological properties and biscuit production from flour blends prepared from cereal based by-products.
\end{abstract} Harran Tarım ve Gıda Bilimleri Dergisi, 23(2): 142-149. DOI: 10.29050/

harranziraat.410059

\section{Address for Correspondence: Sibel YAĞCl \\ e-mail: \\ syagci@kmu.edu.tr}

\section{Received Date:}

27.03.2018

Accepted Date:

09.11 .2018

(C) Copyright 2018 by Harran University Faculty of Agriculture. Available on-line at www.dergipark.gov.tr/harranziraat

\section{ABSTRACT}

The technological advances in the processing of cereal products allow separating of different milling fractions, which can be used as functional additives in food formulations. These byproducts can be used to improve the technological performance and/or to integrate foods with healthy compounds such as dietary fiber, phenolics and antioxidants. In this study, various types of cereal by-products including wheat, barley and oat brans, bulgur bran, poppy waste and wheat germ, were added to the wheat flour. The $10 \%$ of the wheat flour used was replaced with the different cereal by-products. Then, the flour blends and control sample were analyzed using standard "Chopin +" protocol of Mixolab equipment for determination of rheological properties. The same blends were also used for biscuit preparation. The Hunter $L, a, b$ values, spread ratio, hardness and sensory properties of biscuits were measured. Water absorption and dough development time were slightly affected by addition of the products. In general, the addition of the by-products into the flour resulted higher dough stability (3.35-11.22 $\mathrm{min}$ ) and higher torque by $\mathrm{C}_{2}(0.38-0.052$ $\mathrm{Nm}$ ) except for addition of the wheat germ. This indicates strong dough structure. Adding cereal by products except for wheat germ mostly decreased ( $p \leq 0.05$ ) lightness (L), spread ratio and overall acceptance and increased $(p \leq 0.05)$ hardness of biscuit samples.

Key Words: Rheological properties, Biscuit, Cereal by-product, Mixolab

Öz

Tahıl ürünlerinin üretimi sırasında kullanılan teknolojik yöntemler fonksiyonel gıda katkısı olarak kullanılabilecek farklı değirmencilik ara ürünlerinin ayrılmasına olanak sağlar. Bu yan ürünler teknolojik performansı artırmak veya diyet lif, fenolikler ve antioksidanlar gibi sağlığa yarayışlı bileşenlerin gıda formülasyonlarına eklenmesi amacı için kullanılabilirler. Bu çalışmada; buğday, arpa, yulaf ve bulgur kepekleri, haşhaş küspesi, ruşeym gibi birçok tahıl yan ürünleri buğday ununa eklenmiştir. Buğday ununun \%10'u farklı tahıl yan ürünleri ile değiştirilmiştir. Un karışımları ve kontrol numunesi sonrasında Mixolab cihazında standart "Chopint" protokolü kullanılarak reolojik özellikleri açısından test edilmişlerdir. Aynı un karışımları bisküvi yapımında kullanılmıştır. Bisküvilerin Hunter $L, a, b$ değerleri, yayılma oranı, sertlik ve duyusal özellikleri ölçülmüştür. Su emme oranı ve hamur gelişim zamanı bu yan ürünlerin eklenmesinden bir miktar etkilenmiştir. Ruşeym ilavesi dışında tahıl yan ürünlerinin una eklenmesi ile genellikle daha uzun hamur stabilitesi (3.35-11.22 dk) ve daha yüksek tork değerleri $\left(C_{2}\right.$ 0.38-0.052 Nm) elde edilmiştir. Bu durum daha güçlü hamur yapısında işaret eder. Ruşeym ilavesi dışında eklenen tahıl yan ürünleri çoğunlukla bisküvi numunelerinin beyazlığını, yayılma oranının ve genel kabul edilebilirliğini azaltmış; sertliğini artırmıştır.

Anahtar Kelimeler: Reolojik özellikler, Bisküvi, Tahıl yan ürünleri, Mixolab 


\section{Introduction}

The technological advances in the processing of cereal products allow separating of different fractions, which can be used as functional additives in food formulations. These by-products can be used to improve the technological performance and/or to integrate foods with healthy compounds such as dietary fiber, phenolics and antioxidant. It was demonstrated that the concentration of bioactive constituents was greater in the outer layers of the wheat grain; thus the bran fraction demonstrates higher antioxidant activity than other milling fractions (Beta et al., 2005; Esposito et al., 2005; LiyanaPathirana and Shahidi, 2007). Various fiber sources have been developed for use in cereal foods to provide more fiber. It was reported that, some of by-products from durum wheat mainly contain insoluble dietary fiber; while others, containing high amount of soluble dietary fiber, are great of nutritional value. Soluble fiber content ranged between $0.9-4.1 \%$; while insoluble fiber content was between 21 and 64\%. Antioxidant activity is also higher for the internal bran fractions and it increases in fractions having reduced granulometry (Esposito et al., 2005). As phenolic compounds are found to be concentrated in the outermost layers, the bran fractions obtained as milling by-products may be used as a natural source of antioxidants and as a value-added product in the preparation of functional food ingredients and/or for enrichment of certain products (Liyana-Pathirana and Shahidi, 2007). These attributes of cereal by-products could therefore be exploited to upgrade a carbohydrate rich snack food like biscuit and cookies.

Biscuits and cookies represent the largest category of snack items among baked foods all over the world. Biscuits possess several attractive features including wider consumption base, relatively long shelf-life, more convenience and good eating quality (Hooda and Jood, 2005; Baljeet et al., 2014). They are generally made from refined soft wheat products with poor nutritional and quality properties; and contain high amount of fat, sugar and salt. However, they can be very nutritious when enriched with the different nutritious sources like legumes, various cereals and fruit-based wastes (Rababah et al., 2006; Pasha et al., 2011; Baljeet et al., 2014). Some fruit fiber and wheat bran have been used to increase fiber content of wire-cut-cookies, and also to improve texture, color and aroma of the final products (Uysal et al., 2007). Rheological properties of the dough and the final quality parameters of the biscuit products are affected from type and level of the ingredients in the formulation (Pedersen et al., 2005). In this study, different types of cereal by-products were incorporated into the biscuit formulation. The objective of this study was to evaluate the substitution of the different types of cereal byproducts on the rheological properties of biscuit dough and on the main quality parameters of the biscuit produced from this dough.

\section{Materials and Methods}

\section{Raw materials}

Oat bran, bulgur bran, poppy waste, wheat germ, wheat bran and barley bran were the different cereal by-products used in the experiments. All of these were obtained from different cereal processing factories in Karaman, Turkey. The other ingredients were as follows: soft wheat flour, which is suitable for biscuit production, shortening, powdered sugar, salt, and baking powder $\left(\mathrm{NaCO}_{3}\right)$. All of them were obtained from biscuit production factory (Şimşek Biscuit and Chocolate Production Company, Karaman, Turkey). The chemical composition of cereal by-products were measured according to AACC (2002) methods (crude fiber (Method no. 32-10), ash (Method no. 08-03), crude fat (Method no. 30-20), moisture content (Method no. 44-15A), protein content (Method no. 46-30). The results of analyses are given in Table 1. 
Determination of rheological properties using Mixolab ${ }^{\circledR}$

Samples used in the rheological experiments were prepared by the replacement of $10 \%(w / w)$ of the soft wheat flour with the different cereal by-product. Soft wheat flour was used as control sample.

Dough mixing and pasting behaviors of the flour samples were studied using the Mixolab ${ }^{\circledR}$ (Chopin Technologies, Villeneuve La Garenne, France). The Mixolab ${ }^{\circledR}$ is a recording dough mixer used to measure the rheological properties of dough subject to the dual stress of mixing and temperature changes. It measures the torque (in $\mathrm{Nm}$ ) produced by the dough between two mixing blades (Anonymous, 2012). For the analysis of rheological behavior of samples, the standard "Chopint" protocol was followed: initial equilibrium at $30{ }^{\circ} \mathrm{C}$ for $8 \mathrm{~min}$, heating to $90{ }^{\circ} \mathrm{C}$ over $15 \mathrm{~min}$ (at a rate of $4^{\circ} \mathrm{Cmin}^{-1}$ ), holding at 90 ${ }^{\circ} \mathrm{C}$ for $7 \mathrm{~min}$, cooling to $50^{\circ} \mathrm{C}$ over $5 \mathrm{~min}$ (at a rate of $4{ }^{\circ} \mathrm{Cmin}^{-1}$ ) and holding at $50{ }^{\circ} \mathrm{C}$ for $5 \mathrm{~min}$. The mixing speed was kept constant at $80 \mathrm{rpm}$. In the "Chopin+" protocol, the dough weight is 75 grams and the target consistency is $1.1 \mathrm{Nm} \mathrm{(+/-} 0.05$ $\mathrm{Nm})$. The parameters that are obtained from the torque-time curve are given in Figure 1.

\section{Preparation of biscuits with cereal by-products}

The baking process of cookies was carried out for blends of $10 \%(w / w)$, which were prepared by substituting the flour in the cookie formulation with cereal by products, according to the "wirecut cookie" Method No. 10-54 (AACC,2002). After baking, cookies were cooled at room temperature and were packed in polypropylene pouches and sealed until further analysis.

\section{Evaluation of biscuit quality}

Physical characteristics: The AACC Method 1050D (2002) was used to evaluate biscuit width, thickness and spread ratio. Biscuit width (W) was measured by placing 6 biscuits edge-to-edge to get the average width in millimeters. Biscuit thickness $(T)$ was measured by stacking 6 biscuit on top of each other, and restacking in different order and re-measuring them to get the average in millimeters. Spread ratio was then calculated as biscuit width divided by the thickness.

The hardness ( $N$, force) of biscuit samples were measured with a TA-XT2i Texture Analyzer (Texture Technologies Corp, scarsdale, NY/Stable Micro Systems, Godalming, Survey, UK) and the software texture Expert (version 5.1.1). The instrument was fitted to the standard $50 \mathrm{~kg}$ load cell supplied with the texture analyzer. A threepoint bending rig technique was used to break sample at a constant speed of $2 \mathrm{~mm} . \mathrm{s}^{-1}$ against the flat plate fixed on the loading frame. The color measurement was done using HunterLab ColorFlex (Hunter lab, Reston VA) with triplicate measurements. The color values were expressed as L (lightness or darkness), a (redness or greenness), b (yellowness or blueness). Sensory evaluation of cookies: Sensory evaluation of biscuit samples was also performed. The samples, which were coded with different numbers, were presented to the panelists. A 1-5 hedonic scale was used to evaluate the samples and panelists rated each sensory attribute between 1 point (unacceptable) and 5 point (very well).

\section{Statistical analysis}

All analyses were done in triplicate. All results were recorded as means of \pm SE and analysed by SPSS for Windows (ver. 10.0). Duncan's multiple range test was done to test any significant differences between samples ( $p \leq 0.05)$.

\section{Results and Discussion}

\section{Rheological characteristics of the biscuit dough}

The effects of the cereal by-products (wheat bran and poppy waste) addition on the rheological characteristics of the flour, in comparative with the control sample are demonstrated in Figure 2. All the measured values from the mixolab curve also are given in Table 2. The results from mixolab analysis confirm that wheat flour used as control sample is biscuit type flour, according to the reference values reported in the Mixolab manual, once biscuit type 
flour presented water absorption about $50.1 \mathrm{~g}$ per $100 \mathrm{~g}$ and stability less than $5 \mathrm{~min}$ (Anonymous 2012). When the barley, wheat, oat and bulgur brans were added to the flour, the water absorption increased from $50.7 \%(\mathrm{w} / \mathrm{w})$ (control) to $54.5,52.5,53.8$ and $55.8 \%(w / w)$, respectively. Bran parts of the cereals contain high amount of dietary fiber. It was indicated that the increase in the water absorption was caused by the hydrogen bonds, which are constituted as a result of the interaction of hydroxyl groups within the structure of the dietary fiber components with water. Other factors that may affect the WA in blends are the increase in protein content and the amount of damaged starch that might be present as a result of crushing (Kohajdová et al., 2013). The flour with wheat germ and poppy waste (had higher fat content relative to other samples) gave similar water absorption values with the control. No statistical differences were observed for $C_{1}$ torque, which was expected due the variation in the amount of water added to obtain a consistency of $1.1 \pm 0.05 \mathrm{Nm}$.

The strength of the flour containing cereal byproducts could be adjudged from the mixolab data on the basis of dough stability and $C_{2}$. Control flour was weak as it developed quickly $(0.77 \mathrm{~min})$ and $C_{2}$ value less than $0.37 \mathrm{Nm}$ indicating that this dough was less tolerant to mixing. In general, addition of the by-products into the flour resulted higher dough stability (3.35-11.22 $\mathrm{min}$ ) and higher torque by $\mathrm{C}_{2}$ (0.38$0.052 \mathrm{Nm}$ ) except for addition of the wheat germ. High dough stability values are usually related to the strength of flours (Kohajdová et al., 2013). Biscuit wheat varieties are characterized by a lower mixing stability and a high gelatinization $\left(C_{3}\right)$ and a very high retrogradation $\left(C_{5}\right)$. Among the samples, wheat germ added flour gave the minimum torque for the protein weakening $\left(C_{2}\right)$.
Wheat germ has high fat content (Table 1 ) so it probably reduces the mechanical work required for the gluten network formation. On the contrary, poppy waste containing flour had highest torque due to increase of the protein and crude fiber contents relative to the control sample (Table 1 ). The parameter $C_{2}$ (gluten network strength) almost increased ( $p \leq 0.05)$ with the addition of cereal by-products to control sample. Higher $C_{3}$ values were observed for all trials except for wheat germ added flour.

\section{Biscuit quality}

Spread ratio values of fortified biscuits and control samples ranged from 10.37 to 14.45 . It was evident from the results that spread ratio was significantly affected by the addition of cereal by-products (Table 3). Spread ratio of different treatments among which, the highest value was observed in wheat germ (13.65) and the lowest for poppy waste (10.87). The spread ratio of the biscuit samples significantly decreased $(p \leq 0.05)$ compared to the control sample. This could be attributed to the increase in number of hydrophilic sites available that compete for the limited free water in biscuit dough (Rababah et al., 2011; Zucco et al., 2011). Similar results were reported for the cookies enriched with oat bran, soy flour, and black gram flour (Patel and Rao 1995; Sharma and Chauhan 2002; Mridula et al., 2007). It was also implied that the quality of protein may also affect the water absorption characteristics of flour and hence spread ratios of biscuits (Mridula et al., 2007).

The higher protein levels for the cereal byproducts flours used in this study (Table 1) may have contributed to the reduced spread. Hardness, as measured by peak force to snap the biscuit, is a very important property of cookies that contributes to product quality (Zucco et al., 2011). 
Yağcı, 2019. Harran Tarım ve Gıda Bilimleri Dergisi, 23(2):142-149

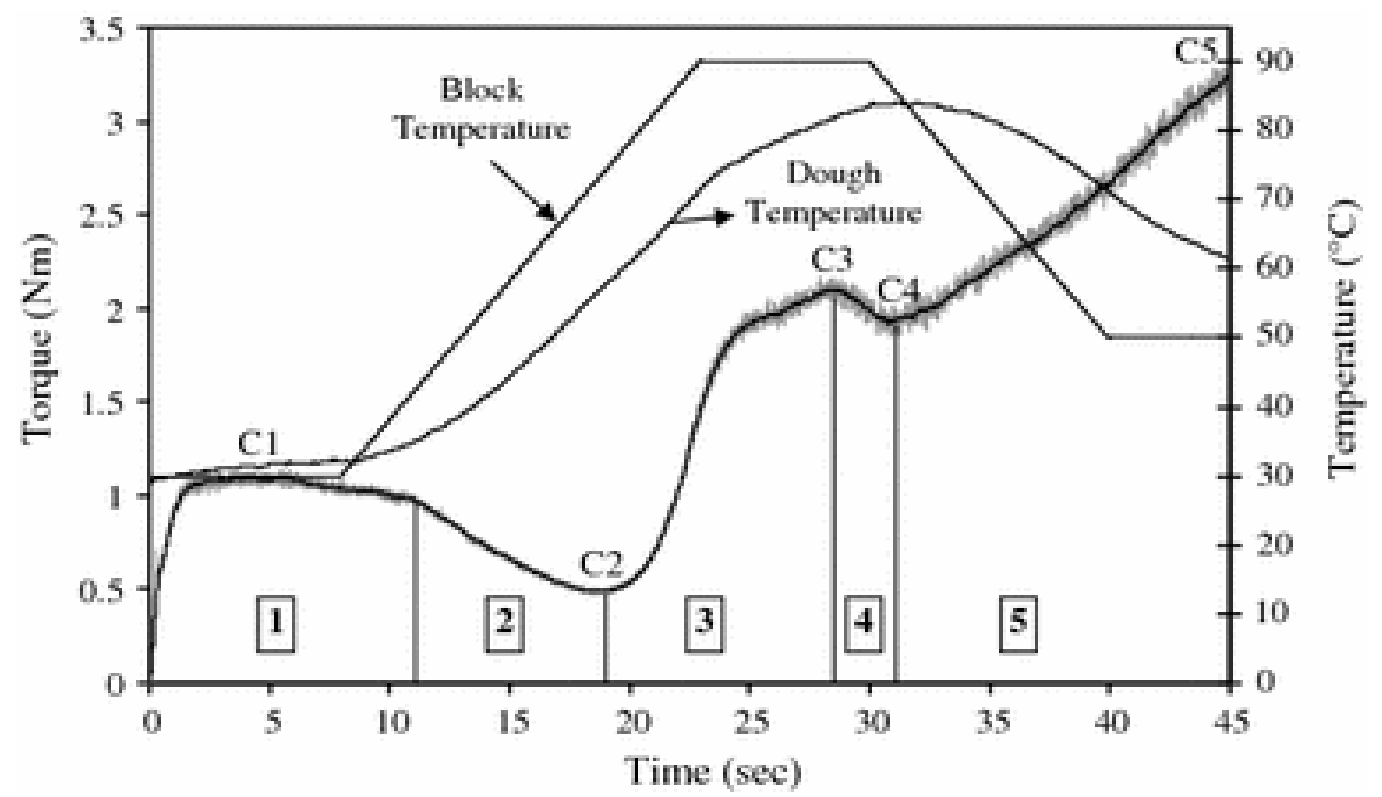

Figure 1. Evaluation of mixolab graph. $C_{1}$ : measures water absorption $(\%, w / w), C_{2}$ : Measures protein weakening as a function of mechanical work and temperature, $C_{3}$ : measures starch gelatinization, $C_{4}$ : measures hot gel stability, $C_{5}$ : measures starch retrogradation in the cooling phase (Anonymous, 2012).

Şekil 1. Mixolab grafiğinin yorumlanması. $C_{1}$ : su emme oranını gösterir (\%), $C_{2}$ : mekanik iş ve sıcaklık etkisi ile protein zayıflamasını gösterir, $C_{3}$ : nişasta çirişlenmesini gösterir, $C_{4}$ : sıcak jel stabilitesini gösterir, $C_{5}$ : soğuma sırasındaki nişasta retrogradasyonunu gösterir (Anonimı, 2012).

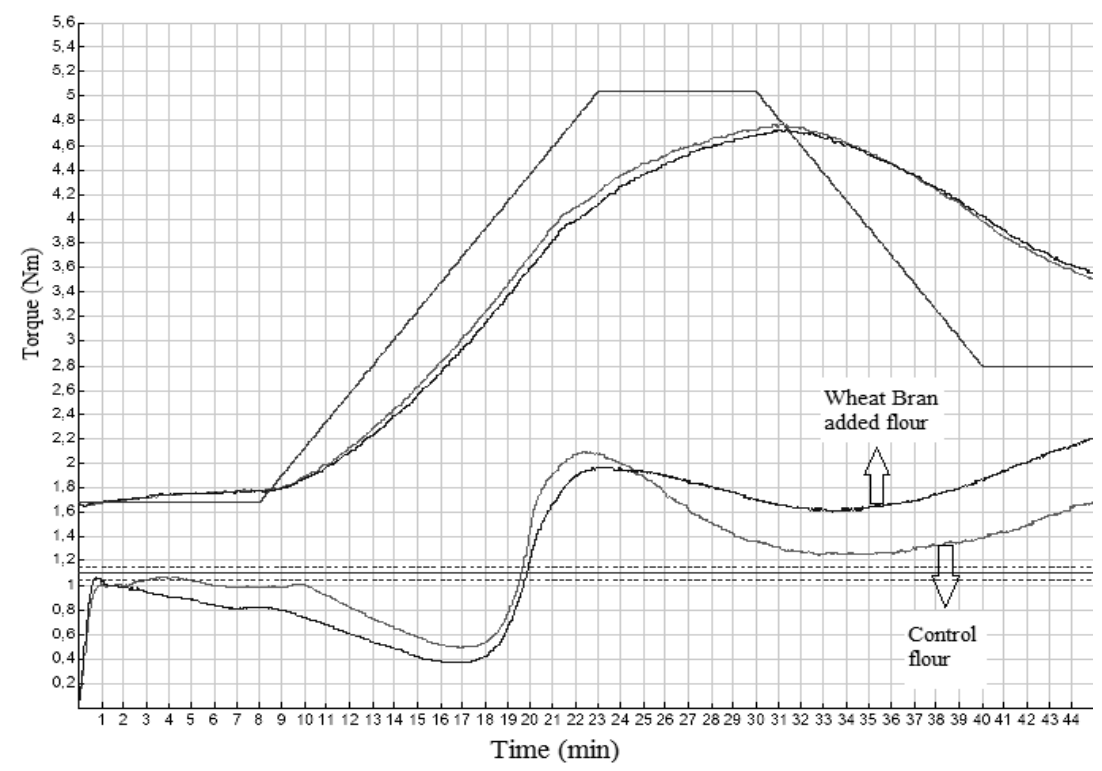

Figure 2. Mixolab graphs for wheat bran added flour and control flour Şekil 2. Buğday kepeği eklenmiş un ile kontrol unun mixolab grafikleri

Table 1. Chemical composition of cereal by-products.

Çizelge 1. Tahıl yan ürünlerinin kimyasal içeriği.

Component

(\%, w/w, wet basis)

Bileşen $(\%, w / w$, ıslak bazda)
Oat Bran Barley Bran Bulgur Bran Wheat Germ Poppy waste Wheat Bran Yulaf kepeği Arpa Kepeği Bulgur Kepeği Ruşeym Haşhaş Küspesi Buğday Kepeği

\begin{tabular}{|c|c|c|c|c|c|c|}
\hline $\begin{array}{l}\text { Moisture } \\
\text { Nem }\end{array}$ & $9.02 \pm 0.47$ & $12.18 \pm 0.20$ & $10.17 \pm 0.21$ & $10.67 \pm 0.27$ & $2.96 \pm 0.37$ & $9.07 \pm 0.24$ \\
\hline $\begin{array}{l}\text { Fat } \\
\text { Yağ }\end{array}$ & $4.22 \pm 0.10$ & $0.59 \pm 0.13$ & $4.18 \pm 0.04$ & $8.09 \pm 0.11$ & $24.17 \pm 0.58$ & $2.67 \pm 0.22$ \\
\hline $\begin{array}{l}\text { Protein } \\
\text { Protein }\end{array}$ & $12.66 \pm 0.18$ & $8.53 \pm 0.14$ & $26.7 \pm 0.64$ & $35.29 \pm 2.05$ & $34.36 \pm 1.14$ & $16.09 \pm 0.11$ \\
\hline $\begin{array}{l}\text { Ash } \\
\text { Kül }\end{array}$ & $3.11 \pm 0.14$ & $2.59 \pm 0.20$ & $1.84 \pm 0.14$ & $0.10 \pm 0.05$ & $2.72 \pm 0.17$ & $5.82 \pm 0.14$ \\
\hline $\begin{array}{l}\text { Crude fiber } \\
\text { Ham Lif }\end{array}$ & $10.89 \pm 0.30$ & $6.71 \pm 0.15$ & $19.60 \pm 0.54$ & $17.65 \pm 0.30$ & $21.65 \pm 0.21$ & $12.87 \pm 0.34$ \\
\hline
\end{tabular}


Table 2. Rheological properties of the flour samples obtained from Mixolab graphs (different letters in the each column show statistical differences at $\mathrm{p} \leq 0.05)$.

Çizelge 2. Un numunelerinin Mixolab grafiklerinden elde edilen reolojik özellikleri (her bir kolondaki farklı harfler istatistiksel olarak farklılı̆̆ı ( $p \leq 0.05)$ gösterir).

\begin{tabular}{|c|c|c|c|c|c|c|c|}
\hline & & & $\mathrm{C}_{1}$ & $\mathrm{C}_{2}$ & $\mathrm{C}_{3}$ & $\mathrm{C}_{4}$ & $C_{5}$ \\
\hline $\begin{array}{l}\text { Samples } \\
\text { Numuneler }\end{array}$ & $\begin{array}{c}\text { Absorption (\%, } \\
w / w) \\
\text { Su Emme Oranı } \\
(\%, w / w)\end{array}$ & $\begin{array}{l}\text { (min) } \\
\text { Hamur Stabilitesi } \\
\text { (dk) }\end{array}$ & $\begin{array}{c}\text { Torque } \\
(\mathrm{Nm}) \\
\text { Tork }(\mathrm{Nm})\end{array}$ & $\begin{array}{c}\text { Torque } \\
\text { (Nm) } \\
\text { Tork } \\
(\mathrm{Nm})\end{array}$ & $\begin{array}{c}\text { Torque (Nm } \\
\text { Tork }(\mathrm{Nm})\end{array}$ & $\begin{array}{c}\text { Torque }(\mathrm{Nm}) \\
\text { Tork }(\mathrm{Nm})\end{array}$ & $\begin{array}{c}\text { Torque }(\mathrm{Nm}) \\
\text { Tork }(\mathrm{Nm})\end{array}$ \\
\hline $\begin{array}{l}\text { Control } \\
\text { Kontrol }\end{array}$ & $50.7 a$ & $3.18 a$ & $1.07 a$ & $0.37 a$ & $1.97 a$ & $1.61 a$ & $2.20 \mathrm{a}$ \\
\hline $\begin{array}{l}\text { Oat Bran } \\
\text { Yulaf Kepeği }\end{array}$ & $53.8 b$ & $9.02 b$ & $1.10 a$ & $0.47 b$ & $2.26 \mathrm{~b}$ & $2.01 \mathrm{~b}$ & $2.82 \mathrm{~b}$ \\
\hline $\begin{array}{l}\text { Barley Bran } \\
\text { Arpa Kepeği }\end{array}$ & $54.5 b$ & $3.83 c$ & $1.07 a$ & $0.38 a$ & $2.15 b$ & $1.11 \mathrm{c}$ & $1.59 c$ \\
\hline $\begin{array}{l}\text { Bulgur Bran } \\
\text { Bulgur Kepeği }\end{array}$ & $55.8 b$ & $3.35 a$ & $1.14 a$ & $0.45 b$ & $2.15 b$ & $1.36 \mathrm{c}$ & $1.98 d$ \\
\hline $\begin{array}{l}\text { Wheat Germ } \\
\text { Ruşeym }\end{array}$ & $50.3 a$ & $4.30 d$ & $1.07 a$ & $0.33 a$ & $1.95 a$ & $1.70 a$ & $2.48 \mathrm{e}$ \\
\hline $\begin{array}{l}\text { Poppy waste } \\
\text { Haşhaş Küspesi }\end{array}$ & $47.1 c$ & $11.22 \mathrm{e}$ & $1.06 a$ & $0.52 b$ & $2.26 \mathrm{~b}$ & $2.11 b$ & $2.62 \mathrm{e}$ \\
\hline $\begin{array}{l}\text { Wheat bran } \\
\text { Buğday Kepeği }\end{array}$ & $52.5 d$ & $5.52 f$ & $1.11 a$ & $0.49 b$ & $2.17 b$ & $1.74 a$ & $2.64 \mathrm{e}$ \\
\hline
\end{tabular}

Table 3. Quality parameters of biscuits produced by blending of cereal by-products and wheat flour (different letters in the each column show statistical differences at $p \leq 0.05)$.

Çizelge 3. Buğday unu ile tahıl yan ürünlerinin karıştırılması ile hazırlanan bisküvilerin kalite parametreleri (her bir kolondaki farklı harfler istatistiksel olarak farklılığı ( $p \leq 0.05)$ gösterir).

\begin{tabular}{|c|c|c|c|c|c|c|c|c|c|}
\hline & & & $\begin{array}{r}\text { Colo } \\
\text { Renk }\end{array}$ & $\begin{array}{l}\text { parame } \\
\text { paramet }\end{array}$ & $\begin{array}{l}\text { ters } \\
\text { releri }\end{array}$ & & $\begin{array}{l}\text { Sens } \\
\text { Duyc }\end{array}$ & $\begin{array}{l}\text { ry Properties } \\
\text { sal Özellikler }\end{array}$ & \\
\hline $\begin{array}{l}\text { Sample } \\
\text { Numune }\end{array}$ & $\begin{array}{c}\text { Spread } \\
\text { Ratio (W/L) } \\
\text { Yayılma } \\
\text { Oranı } \\
\end{array}$ & $\begin{array}{l}\text { Hardness } \\
\qquad(N) \\
\text { Sertlik }(N)\end{array}$ & $L$ & $a$ & $b$ & $\begin{array}{l}\text { Flavor } \\
\text { Lezzet }\end{array}$ & $\begin{array}{c}\text { Appearance } \\
\text { Görünüş }\end{array}$ & $\begin{array}{l}\text { Hardness } \\
\text { Sertlik }\end{array}$ & $\begin{array}{c}\text { General } \\
\text { Acceptability } \\
\text { Genel } \\
\text { kabuledilebilirlik }\end{array}$ \\
\hline $\begin{array}{l}\text { Control } \\
\text { Kontrol }\end{array}$ & $\begin{array}{c}14.45 \\
\pm 0.33 a\end{array}$ & $\begin{array}{c}42.99 \\
\pm 3.81 \mathrm{a}\end{array}$ & $\begin{array}{c}66.12 \\
\pm 3.16 a\end{array}$ & $\begin{array}{c}6.84 \\
\pm 1.02 \mathrm{a}\end{array}$ & $\begin{array}{c}22.98 \\
\pm 1.85 \text { a }\end{array}$ & 4 & 5 & 5 & 4 \\
\hline $\begin{array}{l}\text { Wheat bran } \\
\text { Buğday } \\
\text { Kepeği }\end{array}$ & $\begin{array}{c}12.69 \\
\pm 0.15 \mathrm{~b}\end{array}$ & $\begin{array}{c}47.51 \\
\pm 3.32 \mathrm{~b}\end{array}$ & $\begin{array}{c}59.96 \\
\pm 1.42 \text { b }\end{array}$ & $\begin{array}{c}6.32 \\
\pm 0.12 b\end{array}$ & $\begin{array}{c}19.23 \\
\pm 0.23 \mathrm{~b}\end{array}$ & 4 & 4 & 4 & 4 \\
\hline $\begin{array}{l}\text { Barley Bran } \\
\text { Arpa Kepeği }\end{array}$ & $\begin{array}{c}12.65 \\
\pm 0.20 \mathrm{~b}\end{array}$ & $\begin{array}{c}47.31 \\
\pm 4.10 \mathrm{~b}\end{array}$ & $\begin{array}{c}56.46 \\
\pm 1.14 \mathrm{C}\end{array}$ & $\begin{array}{r}5.57 \\
\pm 0.26 c\end{array}$ & $\begin{array}{c}18.86 \\
\pm 0.63 \mathrm{~b}\end{array}$ & 3 & 3 & 4 & 3 \\
\hline $\begin{array}{l}\text { Oat Bran } \\
\text { Yulaf Kepeği }\end{array}$ & $\begin{array}{c}13.23 \\
\pm 0.16 \mathrm{c}\end{array}$ & $\begin{array}{c}46.86 \\
\pm 3.65 \mathrm{~b}\end{array}$ & $\begin{array}{c}63.79 \\
\pm 2.74 \mathrm{~d}\end{array}$ & $\begin{array}{c}6.50 \\
\pm 0.18 b\end{array}$ & $\begin{array}{c}21.77 \\
\pm 0.58 a\end{array}$ & 5 & 4 & 3 & 4 \\
\hline $\begin{array}{l}\text { Bulgur Bran } \\
\text { Bulgur Kepeği }\end{array}$ & $\begin{array}{c}11.87 \\
\pm 0.21 \mathrm{a}\end{array}$ & $\begin{array}{c}41.66 \\
\pm 2.87 \mathrm{a}\end{array}$ & $\begin{array}{c}61.38 \\
\pm 1.16 \mathrm{~b}\end{array}$ & $\begin{array}{c}6.42 \\
\pm 0.15 b\end{array}$ & $\begin{array}{c}20.33 \\
\pm 0.26 \text { a }\end{array}$ & 3 & 3 & 4 & 3 \\
\hline $\begin{array}{l}\text { Wheat Germ } \\
\text { Ruşeym }\end{array}$ & $\begin{array}{c}13.65 \\
\pm 0.14 \mathrm{c}\end{array}$ & $\begin{array}{l}40.11 \\
\pm 4.4 \mathrm{c}\end{array}$ & $\begin{array}{c}63.88 \\
\pm 1.05 \mathrm{~d}\end{array}$ & $\begin{array}{c}6.47 \\
\pm 0.13 b\end{array}$ & $\begin{array}{c}23.61 \\
\pm 0.87 \mathrm{a}\end{array}$ & 4 & 5 & 4 & 4 \\
\hline $\begin{array}{l}\text { Poppy waste } \\
\text { Haşhaş } \\
\text { Küspesi } \\
\end{array}$ & $\begin{array}{c}10.87 \\
\pm 0.32 \mathrm{~d}\end{array}$ & $\begin{array}{c}45.61 \\
\pm 3.64 \mathrm{~b}\end{array}$ & $\begin{array}{c}59.66 \\
\pm 1.70 \mathrm{~b}\end{array}$ & $\begin{array}{c}6.67 \\
\pm 0.45 b\end{array}$ & $\begin{array}{c}20.15 \\
\pm 0.75 b\end{array}$ & 3 & 3 & 4 & 3 \\
\hline
\end{tabular}

Peak force was significantly increased in comparison to the control sample except from wheat-germ added sample (Table 3). For the type of cereal by-product, no significant differences were usually observed. Zucco et al. (2011) observed that cookies substituted with green lentil, pinto and navy bean flours were harder than the control as in our results. The surface color of a baked product is, together with texture and taste, a very important element for the initial acceptability of baked goods by consumers (Zucco et al., 2011). The lightness value for the control (66.12) was higher than any values seen for biscuits containing cereal by-products. Fortified biscuit samples have also reduced a* (redness) values. Cookies with darker top surfaces, and 
more of a browner color were reported for incorporation of lentil and bean flours (Kohajdová et al., 2013), different pulse flours (Zucco et al. 2011; Rababah et al. 2011) into the wheat flour. The sensory evaluation of biscuits is summarized in Table 3. The results obtained in Table 3 show high sensory ratings for all the selected attributes, scores ranged from 3 (acceptable) to 5 (very well). It was observed that addition of the cereal byproducts into the biscuit formulation usually decreased the sensory scores for flavor, appearance, hardness and overall acceptability. The biscuits prepared by replacing wheat germ, wheat bran and oat bran got highest scores (well) for the sensory evaluation. There was no unacceptable biscuit among the tasted samples. Replacement of refined wheat flour with up to $10 \%$ cereal by-products produced protein and fiber enriched biscuits with desirable overall acceptability.

\section{Conclusions}

The rheological and physical testing methods to predict the quality of the final product showed that it was possible to make biscuit with cereal by-products replacement by these functional ingredients in concentrations that allow maintaining the physical and sensory properties similar to control biscuit. In general, the addition of the cereal by-products into the flour resulted higher dough stability (3.35-11.22 $\mathrm{min}$ ) and higher torque by $\mathrm{C}_{2}(0.38-0.052 \mathrm{Nm})$ except for addition of the wheat germ. The parameter $C_{2}$ (gluten network strength) almost increased ( $p<\leq 0.05)$ for all incorporated flour samples. Adding cereal by products except for wheat germ mostly decreased $(p \leq 0.05)$ lightness $(L)$, spread ratio and overall acceptance and increased $(p \leq 0.05)$ hardness of the biscuits. All of the incorporated biscuit samples were acceptable by the panelists. Detailed work is required to expand the information obtained in the present study using a large number of cereal by-products with different ratios in the various bakery product formulations.

\section{Acknowledgement}

This study has been previously presented in the International Congress on Natural and Engineering Sciences in Belgrade at 21-25 July, 2017.

\section{References}

AACC, (2002). Approved Methods of American Association of Cereal Chemists (AACC). The Association, St Paul, MN.

Anonymous (2012). Mixolab Applications Handbook. France: Chopin technologies.

Baljeet, S. Y., Ritika, B.Y. \& Reena, K. (2014). Effect of incorporation of carrot pomace powder and germinated chickpea flour on the quality characteristics of biscuits. International Food Research Journal, 21(1), 217-222.

Beta, T., Nam, S., Dexter, J.E., Sapirstein, H.D. (2005). Phenolic content and antioxidant activity of pearled wheat and roller-milled fractions. Cereal Chemistry, 82, 390-393.

Esposito, F., Arlotti, G., Bonifati, A.M., Napolitano, A., Vitale, D., Fogliano, V. (2005). Antioxidant activity and dietary fibre in durum wheat bran byproducts. Food Research International, 38, 11671173.

Hooda, S, Jood, S. (2005). Organoleptic and nutritional evaluation of wheat biscuits supplemented with untreated and treated fenugreek flour. Journal of Food Chemistry, 90, 427-35.

Kohajdová, Z., Karovičová, J., Magala M. (2013). Effect of lentil and bean flours on rheological and baking properties of wheat dough. Chemical Papers, 67 (4), 398-407.

Liyana-Pathirana, C.M., Shahidi, F., 2007. Antioxidant and free radical scavenging activities of whole wheat and milling fractions. Food Chemistry, 101: 1151-1157.

Mridula, D., Gupta, R.K., Manikantan, M.R. (2007). Effect of incorporation of sorghum flour to wheat flour on quality of biscuits fortified with soy flour. American Journal of Food Technology, 2, 428-434.

Pasha, I., Rashid, S., Anjum, F.M., Sultan, M.T., Qayyum, M.M.N., Saeed F. (2011). Quality evaluation of wheat-mungbean flour blends and their utilization in baked products. Pakistan Journal of Nutrition, 10 (4), 388-392.

Patel, M. M., Rao, G. V. (1995). Effect of untreated, roasted, and germinated black gram (Phaseolus mungo) flours on the physico-chemical and biscuit (cookie) making characteristics of soft wheat flour. Journal of Cereal Science, 22, $285 \mathrm{e} 291$.

Pedersen, L., Kaack, K., Bergsøe, M.N., Adler-Nissen, J. 
(2005). Effects of Chemical and Enzymatic Modification on Dough Rheology and Biscuit Characteristics. Journal of Food Science, 70, 152158.

Rababah, T.M., Al-Mahasneh, M.A., Ereifej, K.I. (2006). Effect of Chickpea, Broad Bean, or Isolated Soy Protein Additions on the Physicochemical and Sensory Properties of Biscuits. Journal of Food Science, 71(6), 438-442.

Sharma, H.R., Chauhan, G.S. (2002). Effects of stabilized rice bran-fenugreek blends on the quality of breads and cookies. Journal of Food
Science and Technology, 39, 225-33.

Uysal, H., Bilgiçli, N., Elgün A., Ibanoğlu Ş., Herken E.N., Demir K. (2007). Effect of dietary fibre and xylanase enzyme addition on the selected properties of wire-cut cookies. Journal of Food Engineering, 78, 1074-1078.

Zucco,F., Borsuk,Y., Arntfield, S.D. (2011). Physical and nutritional evaluation of wheat cookies supplemented with pulse flours of different particle sizes. LWT - Food Science and Technology, 44, 2070-2076. 